\title{
MODEL EMPIRIS ORGANIZATIONAL CITIZENSHIP BEHAVIOR DAN KINERJA DOSEN PERGURUAN TINGGI SWASTA DI MEDAN
}

\author{
Jufrizen \\ jufrizen@umsu.ac.id \\ Salman Farisi \\ Muhammad Elfi Azhar \\ Raihanah Daulay \\ Fakultas Ekonomi dan Bisnis, Universitas Muhammadiyah Sumatera Utara
}

\begin{abstract}
The research aims to analyze the effect of motivation and organizational climate on the performance of lecturers with organizational citizenship behavior as a mediating variable in Lecturers of Private Universities in Medan. The study population was all lecturers at private universities in Medan. The sample is the lecturers who have functional positions as an expert assistant, senior lecturer and associate professor. The Data analysis method used in this research is the structural equation modeling method. The results showed that work motivation has a significant effect on organizational citizenship behavior and lecturer performance. Organizational climate affects the organizational citizenship behavior and lecturer performance significantly. Then, organizational citizenship behavior has a significant effect on lecturer performance as well. Work motivation and organizational environment are effect on lecturer performance through organizational citizenship behavior. Furthermore, this research encourages the management of Private Universities in Medan must be able to build a good organizational climate by establishing a harmonious relationship between lecturers and leaders as well as among the lectures. The management of universities also was recommended by this research result to provide more comfortable facilities, so eventually can increase the motivation of lectures to carry out their duty better and at the same time will improve the performance of lecturers itself.
\end{abstract}

Key words: motivation; organizational climate; organizational citizenship behavior; performance.

\begin{abstract}
ABSTRAK
Penelitian memiliki tujuan untuk menganalisis pengaruh motivasi dan iklim organisasi terhadap kinerja dosen dengan Organizational citizenship behavior sebagai variabel mediasi pada Dosen Perguruan Tinggi Swasta di Medan. Populasi penelitian adalah seluruh Dosen pada Perguruan Tinggi Swasta (PTS) yang ada di Medan dosen yang memiliki fungsional. Dalam penelitian ini hanya dibatasi pada dosen yang memiliki jabatan fungsional Asisten Ahli, Lektor dan Lektor Kepala yang berdomisili di Medan. Metode analisis data yang digunakan adalah dengan Model Persamaan Struktural. Hasil penelitian menunjukkan bahwa, motivasi kerja berpengaruh signifikan terhadap organizational citizenship behavior, motivasi kerja berpengaruh signifikan terhadap kinerja dosen, iklim organisasi berpengaruh signifikan terhadap organizational citizenship behavior, iklim organisasi berpengaruh signifikan terhadap kinerja dosen dan organizational citizenship behavior berpengaruh signifikan terhadap kinerja Dosen Perguruan Tinggi Swasta di Medan. Serta motivasi kerja dan iklim organisasi berpengaruh terhadap Kinerja Dosen melalui variabel Organizational Citizenship Behaviour. Oleh karena itu penelitian ini, mendorong pihak Manajemen Perguruan Tinggi Swasta di Medan harus dapat membangun iklim organisasi yang baik dengan menjalin hubungan yang harmonis antara dosen dengan pemimpin maupun dosen dengan dosen lainnya dan pihak Manajemen Perguruan Tinggi dapat meningkatkan motivasi dosen dengan memberikan fasilitas yang nyaman, agar para dosen dalam menjalankan aktivitasnya berjalan dengan baik dan nantinya akan meningkatkan kinerja dosen.
\end{abstract}


Kata kunci: motivasi; iklim organisasi; organizational citizenship behavior; kinerja.

\section{PENDAHULUAN}

Komponen terpenting dalam sistem pendidikan tinggi di Indonesia selain mahasiswa dan pegawai adalah dosen. Dosen mempunyai peran, tugas, dan tanggungjawab dalam meningkatkan kualitas manusia dan mencerdaskan kehidupan bangsa (Auliana dan Nurasiah, 2017). Melihat peran tersebut, setiap dosen dituntut untuk selalu meningkatkan diri dan memiliki kinerja tinggi (Hakim dan Fernandes, 2017). Saat ini perhatian terhadap kinerja dosen sudah banyak dilakukan dengan memberikan pelatihan, melakukan studi banding, mengikuti lokakarya atau sejenisnya, dan juga memberikan peluang meningkatkan pendidikan ke jenjang yang lebih tinggi.

Berbicara mengenai kinerja dosen, selalu berkaitan dengan budaya perilaku di dalam organisasi itu sendiri. Organizational citizenship behavior $(O C B)$ merupakan perilaku positif anggota organisasi. Perilaku positif tercerminkan ke dalam bentuk kesediaan untuk bekerja, dan berkontribusi kepada organisasi. Organizational citizenship behavior $(O C B)$ adalah loyalitas, kecintaan dan rasa memiliki dari anggota organisasi kepada organisasinya (Jaya dan Subrata, 2014). organisasi memiliki karyawan dengan Organizational citizenship behavior yang tinggi, berarti organisasi mampu menghadapi tantangan dari perubahan lingkungan internal maupun lingkungan eksternal (Jaya dan Subrata, 2014). Dengan demikian, $O C B$ sangat penting dalam sebuah organisasi demi perbaikan efisiensi, efektivitas, dan kreatifitas organisasi melalui kontribusi anggota organisasi dalam bentuk transformasi sumber daya, inovasi, dan adaptabilitas (Organ, 1988); (Williams dan Anderson, 1991).

Pendidikan dipercaya sebagai salah satu elemen penting dalam pengembangan negara (Arokiasamy et al., 2009). Pendidikan individu adalah sarana untuk masa karir dan mobilitas sosial, sedangkan dari perspektif pemerintah, ini adalah langkah penting dalam pembangunan ekonomi negara (Benjamin et al., 2011). Tenaga kerja penting di universitas itu sendiri, adalah dosen (Arokiasamy et al., 2009). OCB dan kinerja karyawan bisa dipengaruhi dari faktor internal maupun faktor eksternal, salah satunya adalah dari motivasi diri karyawan (Organ et al., 2006). Motivasi didefinisikan sebagai proses pengambilan keputusan kognitif yang memengaruhi ketekunan dan arah tujuan yang diarahkan tingkah laku (Braton dan Gold, 2012). Untuk itu setiap organisasi harus memperhatikan motivasi kerja para dosen, karena motivasi memainkan peran penting dalam meningkatkan kinerja karyawan; dengan demikian, berkontribusi terhadap keseluruhan kinerja organisasi (Malanao et al., 2015).

Iklim organisasi merupakan kualitas yang berkelanjutan di lingkungan pendidikan yang dialami oleh dosen dan berdasarkan persepsi kolektif tentang perilaku dalam organisasi pendidikan dan konstituennya adalah sebagai pengikut (Hoy dan Miskel, 2001). Iklim organisasi diartikan sebagai kualitas lingkungan intern organisasi dimana anggota organisasi merasakan, yang mempengaruhi perilaku dan dijelaskan dalam seperangkat nilai karakteristik tertentu dari organisasi (Subramani et al., 2016). Iklim organisasi yang baik diikuti oleh perilaku anggota organisasi yang baik, serta memberikan efek positif kepada peningkatan kinerja. Semua aktivitas dalam organisasi dapat dilakukan secara baik dan maksimal apabila iklim organisasi cukup kondusif yang akhirnya akan mampu meningkatkan kinerja (Jaya dan Subrata, 2014).

Dalam penelitian yang dilakukan Meylandani (2013) menyatakan bahwa OCB dapat dipengaruhi faktor iklim organisasi. Selanjutnya hasil penelitian (Ibrahim dan Aslinda, 2014) menyimpulkan bahwa selain iklim organisasi, motivasi juga berpengaruh terhadap OCB. Beberapa hasil penelitian menunjukkan bahwa iklim organisasi me- 
miliki pengaruh yang sangat kuat terhadap kinerja (Selamat et al., 2013) dan motivasi kerja berpengaruh terhadap kinerja dosen (Cui et al., 2013); dan (Jayaweera, 2015). Penelitian lain menemukan bahwa OCB berpengaruh terhadap kinerja (Li, 2013); (Sani dan Maharani, 2012).

Sejumlah pertanyaan penelitian antara lain adalah faktor apakah yang sebenarnya yang mempengaruhi Organizational citizenship behavior dan kinerja dosen pada Perguruan Tinggi Swasta (PTS) di Medan? Apakah motivasi dan iklim organisasi berpengaruh terhadap Organizational citizenship behavior dosen Perguruan Tinggi Swasta (PTS) di Medan? Dan apakah Organizational citizenship behavior berpengaruh terhadap kinerja dosen Perguruan Tinggi Swasta (PTS) di Medan?. Hasil penelitian ini diharapkan dapat memberikan implikasi kepada kinerja dosen dan peningkatan kinerja dari Perguruan Tinggi Swasta yang ada di Medan.

\section{TINJAUAN TEORETIS \\ Motivasi Kerja}

Definisi motivasi secara sederhana adalah yang membuat orang mengerahkan upaya dan energi nyata dari apa yang mereka lakukan. Psikolog telah mengeksplorasi cara memotivasi karyawan sejak awal abad terakhir, dan banyak pengetahuan tentang motivasi manusia telah dikembangkan dan diterapkan secara luas (Srivastava dan Barmola, 2011). Motivasi didefinisikan sebagai proses pengambilan keputusan kognitif yang memengaruhi ketekunan dan arah tujuan yang diarahkan tingkah laku (Braton dan Gold, 2012). Motivasi kerja bisa juga dapat diartikan sebagai kekuatan psikologis seseorang yang menentukan arah perilaku orang itu dalam suatu organisasi (George dan Jones, 2012). (Nabi et al., 2017) mendefinisikan motivasi sebagai proses yang dimulai oleh kekurangan kebutuhan fisiologis yang mengaktifkan perilaku atau dorongan yang ditujukan untuk tujuan insentif. Jadi motivasi merupakan karakteristik psikologis manusia dan ini berkontribusi pada tingkat komitmen kerja karyawan. (Saeed et al., 2014) telah mendefinisikan motivasi sebagai psikologis karakteristik karyawan yang mewajibkan mereka untuk bertindak dengan cara khusus. (Jensen, 2018) menyoroti bahwa, untuk memotivasi karyawan, manajer harus mengidentifikasi kebutuhan yang dicari individu dengan memuaskan dan memusatkan bakat karyawan dengan cara yang membantu mereka mencapai kepuasan itu. (Ajayi, 2015) menunjukkan motivasi karyawan sebagai proses pengambilan keputusan pribadi karyawan, di mana karyawan memilih hasil yang dirancang sendiri dan menggerakkan perilaku yang sesuai untuk mereka. Carpenter et al., (2010) memandang motivasi sebagai perilaku yang diarahkan untuk mencapai tujuan. Menurut pandangan Herman et al. (2014) motivasi karyawan berkaitan dengan faktor atau peristiwa yang mengarah, mendorong dan memindahkan interaksi atau tindakan individu tertentu selama periode waktu tertentu, di bawah kondisi yang yang berlaku. Muhammad dan Memon (2012) menunjukkan motivasi sebagai gabungan kekuatan yang menyebabkan karyawan berperilaku positif.

Dalam konteks motivasi kerja, karyawan bertekad untuk melakukan tugas yang ditugaskan kepadanya dengan sebaik mungkin. Motivasi kerja dapat digunakan dalam mencapai tujuan pribadi maupun tujuan organisasi yang mengarah pada kepuasan kebutuhan individu (Gomes et al., 2013). Penelitian yang dilakukan Osman et al., (2015) menyimpulkan bahwa motivasi berpengaruh terhadap OCB. Hasil penelitian (Nzulwa, 2014) menemukan bahwa faktor motivasi memengaruhi kinerja profesional dan guru. Ini didukung oleh teori (Luthans, 2006), yang menyatakan bahwa kondisi psikologis karyawan berupa kepuasan kerja dan motivasi memiliki pengaruh hubungan positif dengan kinerja. Hasil penelitian yang dilakukan Jufrizen (2017) menemukan motivasi memiliki signifikansi dan efek positif pada kinerja. 
Dengan kata lain kinerja adalah fungsi dari motivasi; melalui motivasi seorang individu akan memiliki kinerja yang lebih baik (Rivai, 2005). Luthans (2006) mengungkapkan bahwa motivasi memiliki dampak positif pada kinerja.

$\mathrm{H}_{1}$ : Terdapat pengaruh motivasi terhadap organizational citizenship behavior

$\mathrm{H}_{2}$ : Terdapat pengaruh motivasi terhadap kinerja

\section{Iklim Organisasi}

Iklim organisasi merupakan kepribadian yang membedakannya suatu oragnsiasi dari organisasi lain yang mengarah pada persepsi setiap anggota dalam memandang organisasi (Davis dan Newstrom, 2001). Iklim organisasi diartikan sebagai pendekatan di mana anggota organisasi mengamati dan mengkarakterisasi lingkungan sekitarnya dengan sikap dan berbasis nilai (Thompson, 2005). Dalam perspektif lain, Atkinson dan Frechette, (2017) menyebutkan iklim organisasi sebagai seperangkat atribut khusus organisasi yang dapat diinduksi dari organisasi, berkaitan dengan anggotanya dan lingkungannya. Iklim organisasi didefinisikan sebagai organisasi perasaan atau entitas kolektif. Iklim organisasi adalah kualitas lingkungan internal organisasi dan dijelaskan dengan beberapa atribut sebagai terbuka, hidup, santai, informal, dingin, impersonal, bermusuhan, $\mathrm{kaku}$, dan tertutup (Lunenburg dan Ornstein, 2011). Konstruk iklim telah dipelajari secara luas dan telah terbukti bermanfaat dalam menangkap persepsi tentang konteks kerja (Ostroff et al., 2003). Iklim telah dideskripsikan sebagai deskripsi berdasarkan pengalaman dari lingkungan kerja dan, lebih khusus, persepsi karyawan tentang kebijakan, praktik dan prosedur formal dan informal dalam organisasi mereka (Schneider et al., 2013).

Iklim organisasi berperan penting peran dalam membangun motivasi, meningkatkan semangat, melibatkan orang, menumbuhkan kreativitas, keefektifan, kinerja, dan umumnya berorientasi pada pengetahuan sikap terhadap sumber daya manusia (Mahmoudi, 2013). Iklim kerja yang baik dibuat oleh manajer yang efektif di mana anggota organisasi dapat berkomitmen dan loyal kepada bekerja sambil dapat menghadapi semua hambatan dan hambatan sepanjang jalan (DehdashtiShahrok et al., 2012). Iklim organisasi adalah bermakna bahwa konstruk berimplikasi signifikan untuk memahami perilaku manusia dalam organisasi (Allen, 2003); (Glisson dan James, 2002). Iklim organisasi memiliki hasil penting di tingkat individu, kelompok, dan organisasi; dan dapat sangat memengaruhi kepuasan kerja, kinerja pekerjaan individu, dan kinerja organisasi. Iklim organisasi, juga membantu dalam menentukan keberhasilan organisasi, dan penting untuk mencapai efektivitas organisasi (Purohit dan Wadhwa, 2012).

Organisasi perlu memperhatikan dan menciptakan iklim organisasi yang baik dan kondusif, karena jika iklim organisasi baik dan kondusif maka akan dapat meningkatkan semangat kerja karyawan serta akan berdampak pada OCB. Oleh karena itu dibutuhkan iklim organisasi yang baik dan kondusif untuk dapat meningkatkan OCB para karyawan (Purwanti dan Mafizatun, 2016).

$\mathrm{H}_{3}$ : Terdapat pengaruh Iklim Organisasi terhadap Organizational Citizenship Behavior

$\mathrm{H}_{4}$ : Terdapat pengaruh Iklim Organisasi Terhadap terhadap kinerja

\section{Organizational Citizenship Behavior}

Perilaku kewarganegaraan organisasi (OCB) adalah konsep manajemen yang relatif modern yang telah mendapatkan perhatian banyak peneliti. Sebagian besar studi ini menunjukkan bahwa OCB memiliki efek penting pada organisasi, produktivitas, kompetensi organisasi dan efektivitas organisasi dalam memenuhi tujuan dan meningkatkan moral karyawan (Demirel et al., 2018). OCB didefinisikan sebagai aktivitas seorang karyawan secara sukarela mungkin dihargai atau tidak, tetapi 
itu juga berkontribusi pada organisasi di mana kualitas seluruh karya menjadi referensi di tempat kerja (Colquitt et al., 2012). Mohamed (2016) mendefinisikan OCB sebagai jenis perilaku individu yang memotivasi karyawan untuk pergi di luar level kerja apa yang diharapkan dari mereka oleh organisasi dan deskripsi pekerjaan; manfaat apa baik organisasi maupun karyawan. Organ et al., (2006) mengemukakan lima indikator dari (OCB) yaitu: Altruisme, Sifat berhati-hati, Sportivitas, Ourtessy dan Civic Virtue. Newland (2012) dan Raghoebarsing (2011) juga menjelaskan lima dimensi menggunakan literatur yang ada yaitu Altruisme, Sifat berhati-hati, Sportivitas, Ourtessy dan Civic Virtue.

Menurut Podsakoff et al., (2009) OCB berkontribusi pada organisasi serta meningkatkan produktivitas, menghemat sumber daya yang dimiliki, membantu menjaga fungsi kelompok, mengefektifkan koordinasi, meningkatkan kemampuan organisasi untuk menarik dan mempertahankan karyawan terbaik, meningkatkan stabilitas organisasi dan meningkatkan kemampuan organisasi untuk beradaptasi dengan perubahan lingkungan. Beberapa hasil penelitian sebelumnya menyimpulkan bahwa OCB memiliki dampak terhadap kinerja karyawan (Ticoalu, 2013) dan (Al-Mahasneh, 2015).

$\mathrm{H}_{5}$ : Terdapat pengaruh Organizational Citizenship Behavior terhadap kinerja

\section{Kinerja}

Kinerja penting untuk organisasi karena kinerja karyawan mengarahkan pada kesuksesan bisnis. Dan juga, kinerja penting bagi individu, karena mencapai tugas dapat menjadi sumber kepuasan (Muchhal, 2014). Istilah kinerja oleh banyak ahli yang berbeda, tapi secara prinsip bahwa kinerja mengarahkan kepada suatu proses dalam rangka pencapaian hasil kerja. Jex dan Britt (2008) menyatakan kinerja adalah semua perilaku karyawan dalam pekerjaan atau di tempat kerja. Landy dan Conte (2016) juga menekankan konsep kinerja tentang perilaku yang relevan dengan tujuan organisasi, "prestasi kerja adalah tindakan atau perilaku yang relevan dengan tujuan organisasi; diukur berdasarkan kemampuan masingmasing individu. Yozgat et al., (2013) menyatakan bahwa kinerja sebagai fungsi individu pada tugas-tugas spesifik yang terdiri dari deskripsi pekerjaan standar. Borman et al., (2014) mendefenisikan kinerja sebagai perilaku yang relevan dengan tujuan organisasi dan yang dapat diukur dalam hal kontribusi individu terhadap efektivitas organisasi. Kinerja mengacu pada perilaku yang relevan dengan tujuan organisasi dan dapat diukur dengan kontribusi mereka terhadap efektivitas organisasi (Kartini et al., 2017). Keberhasilan lembaga pendidikan bisa dilihat dari kinerja dosen. Kinerja dosen merupakan kemampuan dosen untuk melaksanakan pekerjaan atau tugas yang diemban dan memiliki kemampuan dalam menyelesaikan pekerjaan (Trisnaningsih, 2011). Pengukuran Kinerja Dosen mengacu pada Tridharma Pendidikan Tinggi (Wijatno, 2009), yaitu melaksanakan pendidikan dan pengajaran, penelitian dan penulisan makalah ilmiah, dan pelayanan kepada masyarakat.

\section{METODE PENELITIAN}

Penelitian ini dilaksanakan di beberapa Perguruan Tinggi Swasta di Medan seperti Universitas Muhamamdiyah Sumatera Utara (UMSU), Universitas Islam Sumatera Utara (UISU), Universitas Muslim Nusantara (UMN), Universitas Alwashliyah (UNIVA) dan Universitas Nahdlatul Ulama Sumatera Utara (UNUSU). Pada penelitian ini populasinya adalah seluruh dosen tetap Perguruan Tinggi Islam Swasta di Kota Medan yang berjabatan fungsional Asisten Ahli, Lektor dan Lektor Kepala dan memiliki karakteristik: (1) masa kerja di atas 1 tahun, (2) berdomisili di Medan dan (3) melakukan Tri Dharma Perguruan Tinggi. Teknik penarikan sampel menggunakan nonprobability sampling. Sedangkan ukuran sampel diperoleh dari besarnya indikator dikalikan dengan 5 sampai dengan 10 (Hair et al., 2014). Karena penelitian ini menggunakan 5 (lima) 
variabel konstruk yang jumlah indikator keseluruhannya sebesar 50 , sehingga sampel yang dibutuhkan dalam studi ini minimal sebanyak $5 \times 50=250$ orang. Pengumpulan data dilakukan dengan menggunakan wawancara dan kuesioner.

Penelitian ini menggunakan empat variabel yaitu motivasi kerja, iklim organisasi, organizational citizenship behavior dan kinerja dosen. Motivasi kerja dan iklim organisasi berperan sebagai variabel independen, organizational citizenship behavior sebagai variabel mediasi, dan kinerja dosen sebagai variabel dependen.

a. Motivasi merupakan dorongan dari dalam diri dosen untuk mencapai tujuan organisasi. Indikator yang digunakan untuk mengukur motivasi kerja yaitu arah perilaku (direction of behavior), tingkat usaha (level of effort), tingkat kegigihan (level of persistence) (Gondokusumo dan Sutanto, 2015).

b. Iklim organisasi merupakan suasana kerja dalam organisasi yang dipersepsikan dan dirasakan oleh anggota organisasi mengenai apa yang terjadi di dalam lingkungan organisasi. Indikator yang dipakai untuk mengukur variabel iklim organisasi kerja ialah tanggung jawab, identitas organisasi, kehangatan, dukungan, konflik, penghargaan, struktur, pengambilan risiko, dan standar penampilan (Litwin dan Stringer, 1968).

c. Organizational citizenship behavior merupakan kesediaan dosen untuk bekerja, membantu, memberikan kontribusinya dan tetap bertahan untuk mencapai tujuan perusahaan. Indikator yang dipakai untuk mengukur variabel organizational citizenship behavior adalah altruism (perilaku menolong), conscientiousness (kesungguhan dalam bekerja), sportmanship (toleransi yang tinggi), courtessy (bersikap sopan) dan civic virtue (mengedepankan kepentingan bersama) (Organ et al., 2006).

d. Kinerja dosen merupakan perilaku yang ditunjukkan oleh dosen dalam kesediaannya melakukan pekerjaan yang rele- van dengan keterampilannya dalam bidang pengajaran. Indikator kinerja dosen adalah pendidikan dan pengajaran, penelitian, pengabdian masyarakat dan kegiatan penunjang (Suryabrata, 2004).

Pengumpulan data dengan melakukan penyebaran kuesioner kepada responden dengan beberapa pertanyaan untuk setiap variabel. Skala pengukuran ini menggunakan skala Likert dengan pembobotan nilai dari pertanyaan yang diberikan adalah sebagai berikut: a) Bobot nilai 1 untuk jawaban sangat tidak setuju, b) Bobot nilai 2 untuk jawaban tidak setuju, c) Bobot nilai 3 untuk jawaban kurang setuju, d) Bobot nilai 4 untuk jawaban setuju, dan e) Bobot nilai 5 untuk jawaban sangat setuju. Model analisis data yang digunakan adalah Model Persamaan Struktural (Structural Equation Model).

Berdasarkan kajian dari beberapa studi terdahulu dan implementasinya di perguruan tinggi swasta, maka susunan awal model penelitian seperti Gambar 1.

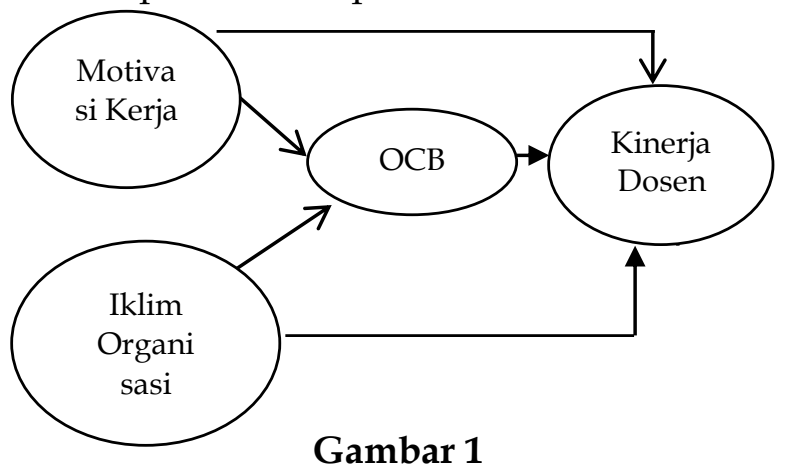

Model Awal Penelitian

\section{ANALISIS DAN PEMBAHASAN \\ Karakteristik Responden}

Hasil penelitian, pengelolaan data dan pembahasan diuraikan dalam bab ini. Sedangkan dikemukakan dalam bab sebelumnya, penelitian ini dilakukan menggunkan metode survey dengan teknik Structural Equation Modeling (SEM). Untuk memperoleh data, penulis menyebarkan kuesioner yang berisi 50 item pernyataan pada responden sebanyak 250 responden yang relevan untuk mendukung penelitian 
ini yang menjadi responden. Dari 250 Set kuesioner penelitian yang dibagikan, kembali sebanyak 241 Set dan yang cacat sebanyak lima (5) set, Jadi kuesioner yang bisa digunakan untuk melakukan analisis data hanya sebanyak 236 Set. Kuesioner yang digunakan dalam pengumpulan data internal, yang kemudian dipilah menggunakan instrumen Skala Likert, dan diolah menggunakan SEM. Evaluasi terhadap model SEM juga dianalisis untuk mendapatkan dan mengevaluasi kecocokan model yang diajukan. Setelah diketahui semua hasil pengolahan data, selanjutnya dibahas dan yang terakhir menarik simpulan yang didasarkan pada hasil analisis tersebut.

Untuk mengetahui identitas res- ponden maka dapat dilihat pada Tabel 1 karakteristik responden berikut ini:

Tabel 1

Karakteristik Responden

\begin{tabular}{|c|c|c|c|c|}
\hline No. & Karakteristik & Deskripsi & Frek & $\%$ \\
\hline \multirow{2}{*}{1} & Jenis Kelamin & Laki-laki & 128 & $54 \%$ \\
\hline & & Wanita & 108 & $46 \%$ \\
\hline \multirow[t]{4}{*}{2} & Umur & 25-30 Tahun & 30 & $13 \%$ \\
\hline & & 31-40 Tahun & 68 & $29 \%$ \\
\hline & & 41-50 Tahun & 102 & $43 \%$ \\
\hline & & $>50$ Tahun & 36 & $15 \%$ \\
\hline \multirow[t]{3}{*}{3} & Jenjang Pendidikan & Strata-1 & 4 & $2 \%$ \\
\hline & & Strata-S2 & 199 & $84 \%$ \\
\hline & & Strata-S3 & 33 & $33 \%$ \\
\hline \multirow[t]{3}{*}{4} & Kepangkatan & Asisten Ahli & 78 & $33 \%$ \\
\hline & & Lektor & 93 & $39 \%$ \\
\hline & & Lektor Kepala & 65 & $28 \%$ \\
\hline \multirow[t]{5}{*}{5.} & Asal Universitas & UMSU & 106 & $45 \%$ \\
\hline & & UISU & 67 & $28 \%$ \\
\hline & & UMN & 41 & $17 \%$ \\
\hline & & UNIVA & 15 & $6 \%$ \\
\hline & & UNUSU & 7 & $3 \%$ \\
\hline \multirow[t]{2}{*}{6.} & Studi Lanjut & Studi Lanjut & 17 & $7 \%$ \\
\hline & & Tidak Studi Lanjut & 219 & $93 \%$ \\
\hline
\end{tabular}

Sumber: Diolah dari kuesioner

a. Karakteristik responden berdasarkan jenis kelamin dapat dilihat bahwa responden yang masing-masing terdiri dari 128 orang laki-laki (54\%) dan 108 orang wanita $(46 \%)$. Jumlah persentase yang cukup berimbang antara laki-laki dan wanita memberi makna bahwa profesi dosen bisa dijalankan oleh siapa saja yang mempunyai kemampuan dan memenuhi persyaratan akademik sebagai dosen serta tidak tergantung pada jenis kelamin tertentu. b. Karakteristik responden berdasarkan kelompok umur menunjukkan bahwa banyaknya responden pada kelompok umur 25-30 tahun adalah 30 orang (13\%), $31-40$ tahun sebanyak 68 orang (29\%), 4150 tahun sebanyak 102 orang (43\%) dan yang berumur 50 tahun ke atas sebanyak 36 orang $(15 \%)$. Karakteristik demografi responden berdasarkan umur dosen, menunjukkan sebagian besar umur responden antara 41 sampai dengan 50 tahun sebanyak 43\%. Pada usia ini 
termasuk usia produktif dan masa purna tugas yang masih lama, sehingga sangat potensial untuk melakukan pengembangan (promosi jabatan struktural dan fungsional). Sementara yang berusia kurang dari 41 tahun sebanyak $42 \%$ merupakan usia yang masih muda, pengalaman masih kurang, tetapi sangat energik dan produktif untuk terus berkembang. Karakteristik responden yang berusia di atas 50 tahun sebanyak 15\% biasanya relatif kurang produktif tetapi sudah sangat matang sebagai seorang pendidik. Hal ini memberikan arti bahwa komposisi usia yang demikian, sebagian besar dosen PTS di Kota Medan berada dalam usia kerja produktif.

c. Karakteristik responden berdasarkan jenjang pendidikan menunjukkan bahwa responden yang memiliki pendidikan formal terakhir Strata-I sebanyak 4 orang $(2 \%)$, Strata-2 sebanyak 199 orang $(84 \%)$ dan Strata-3 sebanyak 33 orang (14\%) hal ini sesuai dengan sasaran dalam penelitian ini, bahwa obyek penelitian adalah dosen yang mensyaratkan berpendidikan minimal S2 atau S1 dengan jabatan fungsional lektor kepala.

d. Karakteristik responden berdasarkan kepangkatan menunjukkan bahwa responden yang memiliki kepangkatan Asisten Ahli sebanyak 78 orang (33\%), Lektor sebanyak 93 orang (39\%) dan Lektor Kepala sebanyak 65 orang (28\%). Hal itu sejalan dengan kondisi rata-rata usia responden yang berkisar antara 41-50 tahun. Kondisi ini menunjukkan bahwa tingkat kematangan dan pengalaman menjadi dosen sudah cukup tinggi sehingga jika kinerja dan pendidikan mereka terus berkembang maka dalam 10 tahun kedepan sangat potensial untuk bisa mencapai jabatan fungsional guru besar.

e. Karakteristik responden berdasarkan asal perguruan tinggi, menunjukkan bahwa banyaknya responden dari UMSU adalah 106 orang (45\%), UISU sebanyak 67 orang (28\%), UMN sebanyak 41 orang (17\%),
UNIVA sebanyak 15 orang $(6 \%)$ dan dari UNUSU sebanyak 7 orang (3\%). Hal ini dapat menunjukan bahwa akreditasi dari perguruan tinggi akan mempengaruhi jumlah mahasiswa sehingga juga berdampak terdapat jumlah dosen yang mengajar di Perguruan Tinggi tersebut.

f. Karakteristik responden berdasarkan proses studi lanjut menunjukkan bahwa sebagian besar responden dosen tidak sedang studi lanjut yaitu sebanyak $93 \%$. Sedangkan responden yang sedang studi lanjut ke jenjang S3 (doktor) hanya sebesar 7\%. Hal ini menunjukkan bahwa minat dosen untuk meningkatkan jenjang pendidikannya masih rendah, dan mereka merasa sudah cukup puas dengan pendidikan dan status sertifikasi yang diperoleh saat ini. Hal tersebut mungkin disebabkan salah satunya adalah faktor biaya, akses beasiswa yang terbatas atau faktor personal lainnya. Pada tahuntahun mendatang kemungkinan dosen yang mau studi lanjut ke S3 akan semakin besar mengingat akses beasiswa studi lanjut (BPPDN dan BPPLN) sudah semakin mudah dengan kuota yang semakin meningkat.

\section{Analisis Validitas dan Reliabilitas Model Pengukuran}

Gambar 2 terlihat bahwa persamaan pengukuran untuk koefisien Eksogen masing-masing indikator memiliki t-value $\geq$ 1.96 yang berarti bahwa indikator-indikator Eksogen semuanya valid dan signifikan secara statistik dengan tingkat signifikansi sebesar 5\%.

Dari gambar 3 terlihat bahwa standardized loading factor $(\lambda)$ variabel indikator yang paling dominan terdapat pada variabel Eksogen motivasi yaitu pada M7 atau pada indikator mengajar selalu tepat waktu, hal ini terlihat dari standardized loading faktor yang lebih besar dari lainnya yaitu sebesar 0,76, sedangkan variabel indikator yang paling dominan terdapat pada variable Eksogen iklim organisasi yaitu pada IO5 atau pada indikator dalam menjalankan 
tugas, saya diberikan kebebasan mengambil keputusan, hal ini terlihat dari standardized loading factor yang lebih besar dari lainnya yaitu sebesar 0,81 .

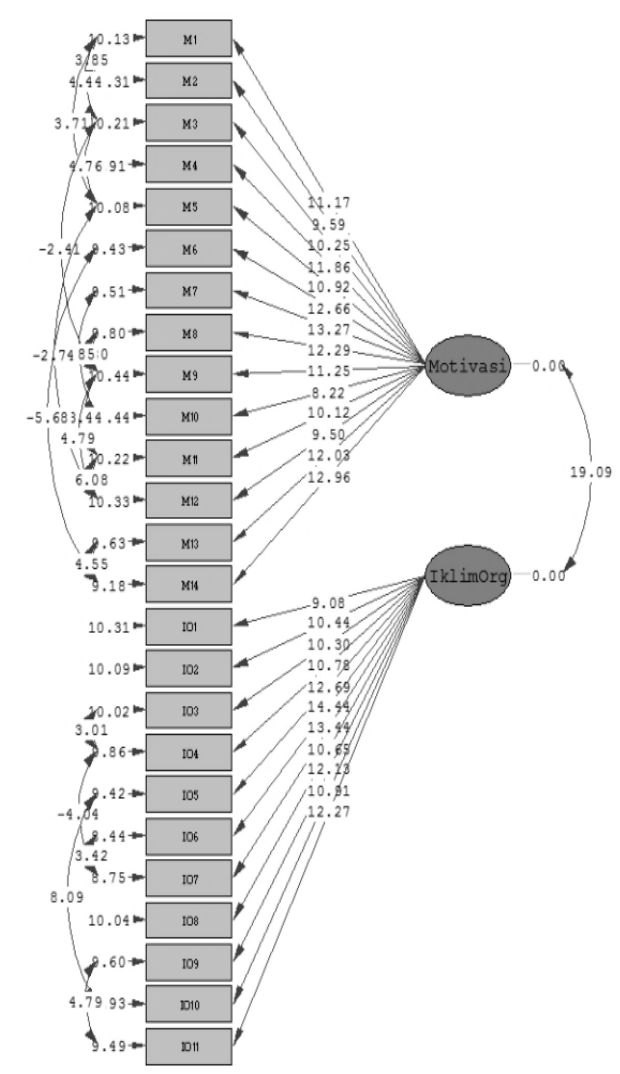

Chi-Square $=548.75, d f=255, \mathrm{P}-$ value $=0.00000, \mathrm{RMSEA}=0.070$

Gambar 2

Path Variabel Eksogen (t-value)

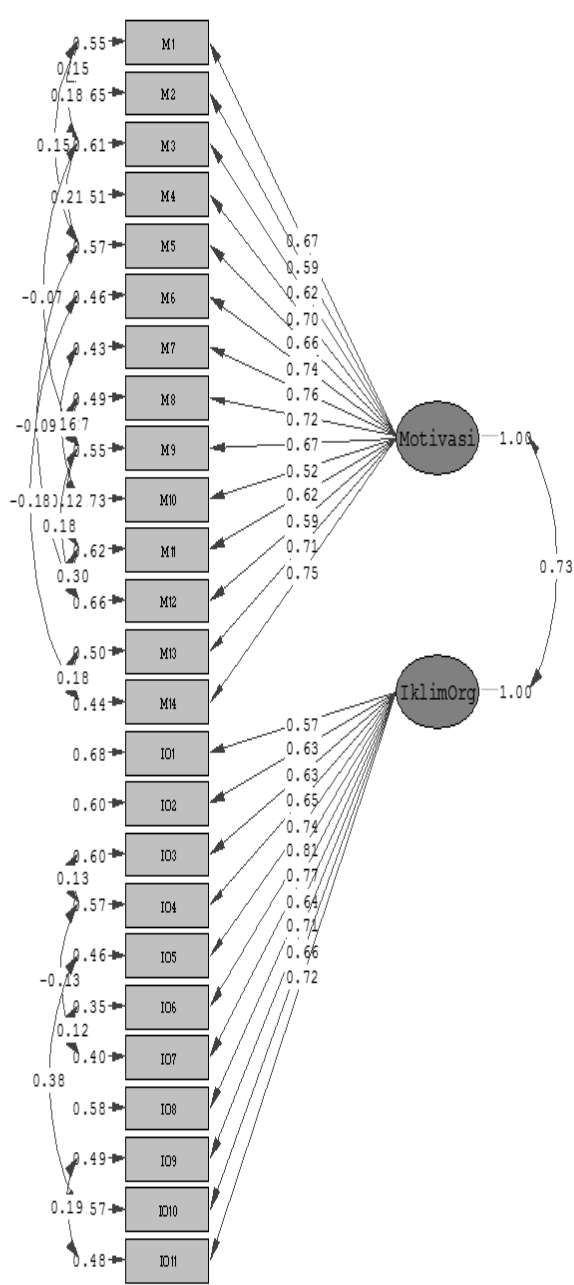

Chi-Square $=548.75, \mathrm{df}=255, \mathrm{P}$-value $=0.00000, \mathrm{RMSEA}=0.070$

Gambar 3

Path Variabel Eksogen (standardized Solution)

Tabel 2

Realibilitas Variabel Eksogen

\begin{tabular}{|c|c|c|c|c|c|c|c|c|}
\hline \multirow{2}{*}{ Indikator } & \multirow{2}{*}{ SLF } & \multirow{2}{*}{ Error } & \multicolumn{6}{|c|}{ Construct Reliability } \\
\hline & & & $\sum$ SLF & $\left(\sum S L F\right)^{2}$ & $\sum$ SLF $^{2}$ & Eerror & Nilai CR & Nilai VE \\
\hline \multicolumn{9}{|c|}{ Motivasi } \\
\hline M1 & 0.67 & 0.551 & \multirow{12}{*}{9.320} & \multirow{12}{*}{86.862} & \multirow{12}{*}{6.269} & \multirow{12}{*}{7.731} & \multirow{12}{*}{0.918} & \multirow{12}{*}{0.448} \\
\hline M2 & 0.59 & 0.652 & & & & & & \\
\hline M3 & 0.62 & 0.616 & & & & & & \\
\hline M4 & 0.7 & 0.510 & & & & & & \\
\hline M5 & 0.66 & 0.564 & & & & & & \\
\hline M6 & 0.74 & 0.452 & & & & & & \\
\hline M7 & 0.76 & 0.422 & & & & & & \\
\hline M8 & 0.72 & 0.482 & & & & & & \\
\hline M9 & 0.67 & 0.551 & & & & & & \\
\hline M10 & 0.52 & 0.730 & & & & & & \\
\hline M11 & 0.62 & 0.616 & & & & & & \\
\hline M12 & 0.59 & 0.652 & & & & & & \\
\hline
\end{tabular}




\begin{tabular}{|c|c|c|c|c|c|c|c|c|}
\hline M13 & $\begin{array}{l}0.71 \\
\end{array}$ & 0.496 & & & & & & \\
\hline M14 & 0.75 & 0.438 & & & & & & \\
\hline & Iklin & anisasi & & & & & & \\
\hline IO1 & 0.57 & 0.675 & \multirow{11}{*}{7.530} & \multirow{11}{*}{56.701} & \multirow{11}{*}{5.206} & \multirow{11}{*}{5.795} & \multirow{11}{*}{0.907} & \multirow{11}{*}{0.473} \\
\hline IO2 & 0.63 & 0.603 & & & & & & \\
\hline IO3 & 0.63 & 0.603 & & & & & & \\
\hline IO4 & 0.65 & 0.578 & & & & & & \\
\hline IO5 & 0.74 & 0.452 & & & & & & \\
\hline IO6 & 0.81 & 0.344 & & & & & & \\
\hline IO7 & 0.77 & 0.407 & & & & & & \\
\hline IO8 & 0.64 & 0.590 & & & & & & \\
\hline IO9 & 0.71 & 0.496 & & & & & & \\
\hline IO10 & 0.66 & 0.564 & & & & & & \\
\hline IO11 & 0.72 & 0.482 & & & & & & \\
\hline
\end{tabular}

Dari perhitungan pada Tabel 2, dapat dilihat bahwa nilai dari construct reliability secara keseluruhan pada Eksogen adalah diatas 0,70, sedangkan varians extracted merupakan opsional dalam menentukan tingkat reliabilitas laten variable masingmasing melebihi $40 \%$ pada variable Eksogen. Hal ini menunjukkan bahwa reliabilitas model pengukuran ini konstruk Eksogen (Motivasi dan Iklim Organisasi) didukung oleh data yang diperoleh.

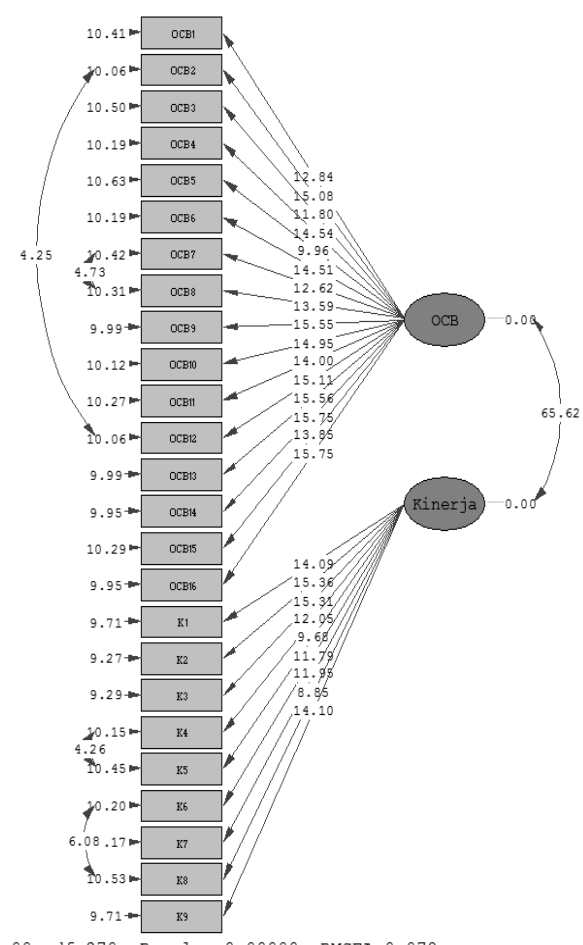

Chi-Square $=657.00, \mathrm{df}=270, \mathrm{P}-\mathrm{value}=0.00000, \mathrm{RMSEA}=0.078$

Gambar 4

Path Variabel Endogen (t-value)
Berdasarkan gambar 4 dapat dilihat bahwa persamaan pengukuran untuk koefisien Endogen masing-masing indikator memiliki $t$-value $\geq 1,96$ yang berarti bahwa indikator-indikator Endogen semuanya valid dan signifikan secara statistik dengan tingkat signifikansi sebesar 5\%.dan tidak perlu ada pembuangan indikator.

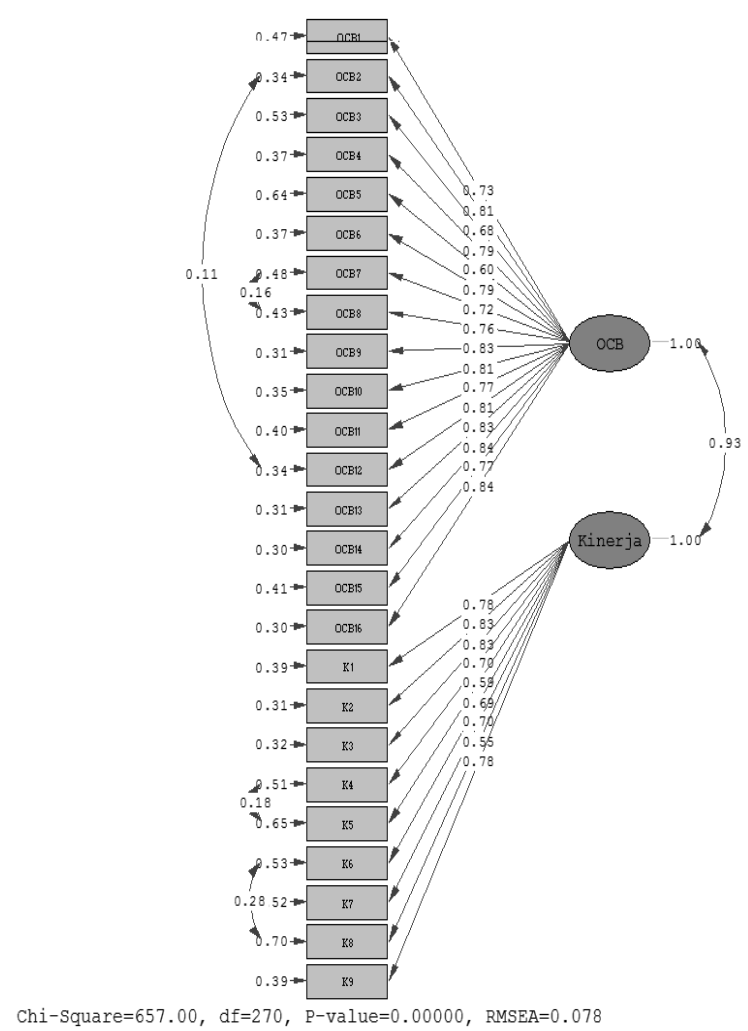

Gambar 5

Path Variabel Endogen (standardized Solution) 
Berdasarkan Gambar 5 dapat dilihat bahwa standardized loading factor $(\lambda)$ variabel indikator yang paling dominan terdapat pada variabel Endogen OCB yaitu pada OCB14 atau 14. Kesediaan saya untuk senantiasa meningkatkan kompetensi kepribadian demi pengembangan diri saya sebagai seorang dosen dan pada OCB16 atau 16 yaitu tentang kesediaan untuk senantiasa meningkatkan kompetensi sosial demi pengembangan diri sebagai seorang dosen, hal ini terlihat dari standardized loading factor yang lebih besar dari lainnya yaitu sebesar 0,84 . Indikator yang paling dominan pada variabel Endogen Kinerja Dosen yaitu pada K2. Hal ini terlihat dari standardized loading factor yang lebih besar dari lainnya yaitu sebesar 0.83

Tabel 3

Realibilitas Variabel Endogen

\begin{tabular}{|c|c|c|c|c|c|c|c|c|}
\hline \multirow[b]{2}{*}{ Indikator } & \multirow[b]{2}{*}{ SLF } & \multirow[b]{2}{*}{ Error } & \multicolumn{6}{|c|}{ Construct Reliability } \\
\hline & & & $\sum$ SLF & $\left(\sum \mathrm{SLF}\right)^{2}$ & $\sum \mathrm{SLF}^{2}$ & $\sum$ error & $\begin{array}{c}\text { Nilai } \\
\text { CR }\end{array}$ & Nilai VE \\
\hline \multicolumn{9}{|c|}{ OCB } \\
\hline OCB1 & 0.73 & 0.467 & \multirow{16}{*}{12.380} & \multirow{16}{*}{153.264} & \multirow{16}{*}{9.643} & \multirow{16}{*}{6.357} & \multirow{16}{*}{0.960} & \multirow{16}{*}{0.603} \\
\hline OCB2 & 0.81 & 0.344 & & & & & & \\
\hline OCB3 & 0.68 & 0.538 & & & & & & \\
\hline OCB4 & 0.79 & 0.376 & & & & & & \\
\hline OCB5 & 0.6 & 0.640 & & & & & & \\
\hline OCB6 & 0.79 & 0.376 & & & & & & \\
\hline OCB7 & 0.72 & 0.482 & & & & & & \\
\hline OCB8 & 0.76 & 0.422 & & & & & & \\
\hline OCB9 & 0.83 & 0.311 & & & & & & \\
\hline OCB10 & 0.81 & 0.344 & & & & & & \\
\hline OCB11 & 0.77 & 0.407 & & & & & & \\
\hline OCB12 & 0.81 & 0.344 & & & & & & \\
\hline OCB13 & 0.83 & 0.311 & & & & & & \\
\hline OCB14 & 0.84 & 0.294 & & & & & & \\
\hline OCB15 & 0.77 & 0.407 & & & & & & \\
\hline OCB16 & 0.84 & 0.294 & & & & & & \\
\hline \multicolumn{9}{|c|}{ Kinerja } \\
\hline K1 & 0.78 & 0.392 & \multirow{9}{*}{6.450} & \multirow{9}{*}{41.603} & \multirow{9}{*}{4.701} & \multirow{9}{*}{4.299} & \multirow{9}{*}{0.906} & \multirow{9}{*}{0.522} \\
\hline $\mathrm{K} 2$ & 0.83 & 0.311 & & & & & & \\
\hline K3 & 0.83 & 0.311 & & & & & & \\
\hline K4 & 0.7 & 0.510 & & & & & & \\
\hline K5 & 0.59 & 0.652 & & & & & & \\
\hline K6 & 0.69 & 0.524 & & & & & & \\
\hline K7 & 0.7 & 0.510 & & & & & & \\
\hline K8 & 0.55 & 0.698 & & & & & & \\
\hline K9 & 0.78 & 0.392 & & & & & & \\
\hline
\end{tabular}

Dari perhitungan pada Tabel 3 dapat dilihat bahwa nilai dari construct reliability secara keseluruhan pada Endogen adalah lebih dari 0,70. Sedangkan varians extracted merupakan opsional dalam menentukan tingkat reliabilitas laten variable masingmasing lebih dari $40 \%$ pada variable Endo- gen. Hal ini menunjukkan bahwa reliabilitas model pengukuran ini konstruk Endogen didukung oleh data yang diperoleh.

\section{Analisis Model Struktural}

Setelah melakukan perhitungan dan analisis terhadap Confirmatory Factor Analysis 
(CFA), maka dapat diukur latent score variabel (LVS) untuk masing-masing dimensi guna direduksi menjadi indikator pada setiap variabel.

Tabel 4

Goodness of Fit Structural Equation Model (SEM)

\begin{tabular}{lll}
\hline \hline Ukuran GoF & Nilai & $\begin{array}{l}\text { Tingkat } \\
\text { Kecocokan }\end{array}$ \\
\hline$\chi^{2} / \mathrm{df}$ & 2.294 & GoodFit \\
Root Mean Square Error of & 0.074 & Good Fit \\
Approximation (RMSEA) & 0,97 & Good Fit \\
Non-Normed Fit Index (NNFI) & 0.96 & Good Fit \\
Normed Fit Index (NFI) & 0.95 & Good Fit \\
Relative Fit Index (RFI) & 0,98 & Good Fit \\
Incremental Fit Index (IFI) & 0,98 & Good Fit \\
Comparative Fit Index (CFI) & & \\
\hline
\end{tabular}

Pada Tabel 4 kita bisa melihat nilai $\chi^{2} / \mathrm{df}$ sebesar 2,294 yang masuk ke dalam kategori good fit karena masih dibawah 5. Nilai RMSEA, NFI, dan RFI NNFI, IFI, dan CFI semuanya masuk ke dalam kategori good fit.

\section{Analisis Hubungan Kausal}

Pengujian hubungan kausal model struktural menggunakan tingkat signifikansi $5 \%$ sehingga nilai kritis dari t-value adalah \pm 1,96. Hasil hubungan kausal penelitian dapat dilihat pada Gambar 6.

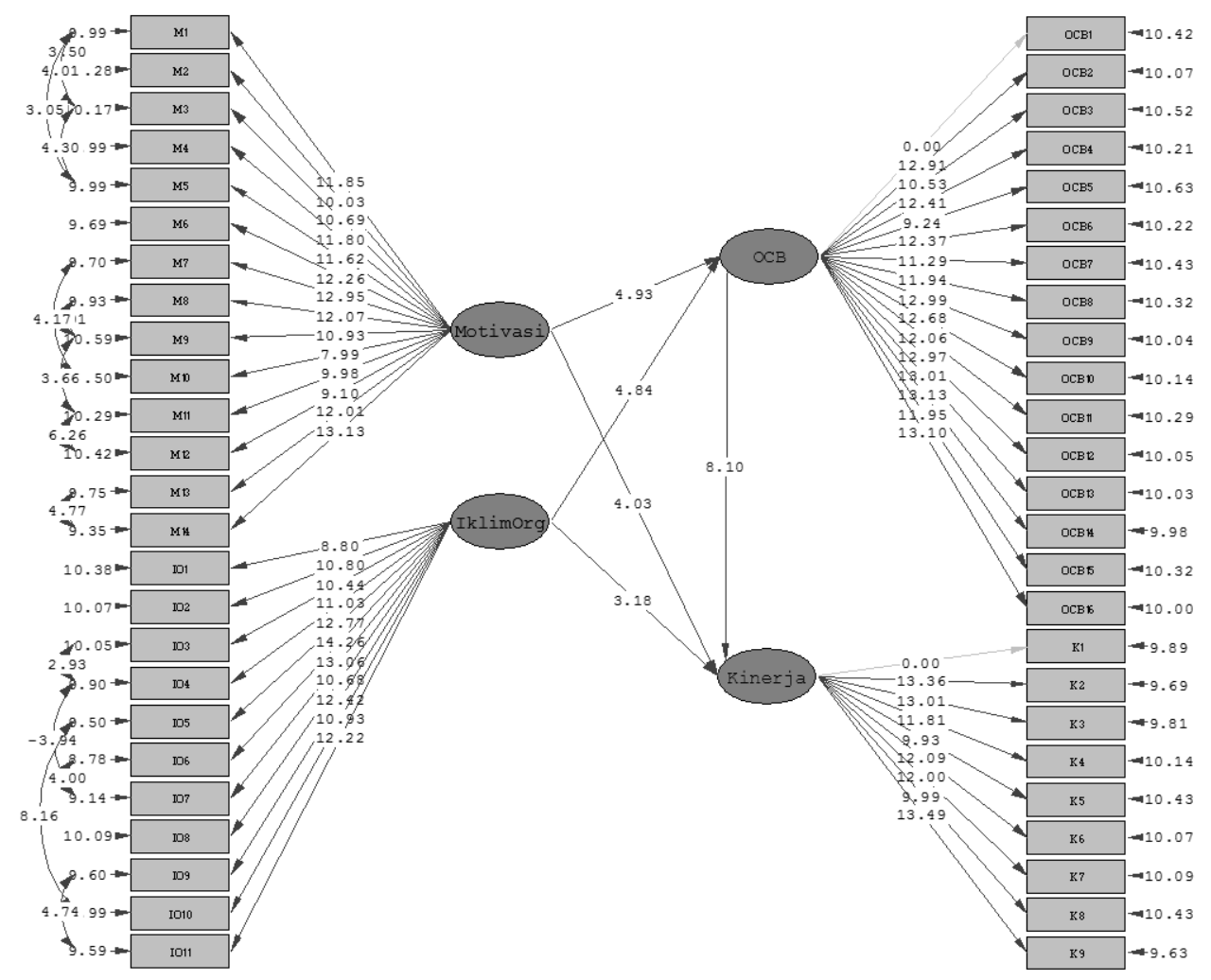

Chi-Square=2636.39, df=1150, P-value=0.00000, RMSEA=0.074

Gambar 6

Model Struktural (t-values) 


\section{Pengujian Hipotesis}

Pengujian hipotesis dilakukan dengan tingkat signifikansi $5 \%$, sehingga menghasilkan critical t-value sebesar $\pm 1,96$. Hipotesis diterima jika $t$-value $\geq 1,96$, sedangkan hipotesis ditolak apbila t-value $<1,96$. Berikut ini adalah Tabel 5 dari pengujian hipotesis:

Tabel 5

Pengujian Hipotesis Langsung

\begin{tabular}{|c|c|c|c|c|}
\hline Hipotesis & Pernyataan & T-Hitung & T-Tabel & Keterangan \\
\hline $\mathrm{H}_{1}$ & Motivasi Kerja $\rightarrow$ OCB & 4.93 & \multirow{5}{*}{1,96} & Signifikan \\
\hline $\mathrm{H}_{2}$ & Motivasi Kerja $\rightarrow$ Kinerja Dosen & 4.03 & & Signifikan \\
\hline $\mathrm{H}_{3}$ & Iklim Organisasi $\rightarrow$ OCB & 4.84 & & Signifikan \\
\hline $\mathrm{H}_{4}$ & Iklim Organisasi $\rightarrow$ Kinerja Dosen & 3.18 & & Signifikan \\
\hline $\mathrm{H}_{5}$ & OCB $\rightarrow$ Kinerja Dosen & 8.10 & & Signifikan \\
\hline
\end{tabular}

Tabel 6

Pengujian Hipotesis Model Penelitian Tidak Langsung

\begin{tabular}{lc}
\hline \hline \multicolumn{1}{c}{ Hipotesis } & Intervening \\
\hline Pengaruh Variabel Tidak Langsung (thitung) & OCB \\
\hline Motivasi Kerja berpengaruh terhadap Kinerja Dosen & 4.56 \\
\hline Iklim Organisasi berpengaruh terhadap Kinerja Dosen & 4.47 \\
\hline
\end{tabular}

\section{Pembahasan Hasil Penelitian}

Pengaruh Motivasi Kerja terhadap Organizational Citizenship Behavior

Berdasarkan hasil pada Tabel 5, diketahui hasil t-value sebesar 4,93 > 1,96, dapat diketahui bahwa motivasi kerja memiliki pengaruh positif terhadap organizational citizenship behavior secara signifikan. Hal ini berarti bahwa semakin tinggi Motivasi Kerja dosen, maka Organizational citizenship behavior akan semakin baik pula. Hasil penelitian mengindikasikan bahwa motivasi kerja memiliki pengaruh positif dan signifikan terhadap OCB dosen Perguruan Tinggi Swasta di Medan, dan dalam konteks motivasi kerja, hal ini terkait dengan tekad para dosen untuk melakukan tugas yang ditugaskan kepadanya dengan sebaik mungkin. Dengan adanya motivasi kerja yang tinggi dari dosen dapat digunakan untuk pencapaian tujuan pribadi dan tujuan organisasi yang mengarah pada pemuasan kebutuhan individu tertentu (Gomes et al., 2013). Hasil penelitian ini sejalan dengan hasil penelitian (Penggalih dan Zulaicha, 2012); (Oren et al., 2013); (Ibrahim dan Aslinda, 2014); (Ariyani et al., 2016); (Hemakumara et al., 2018) dan (Tunggal et al., 2018) yang menyimpulkan bahwa motivasi kerja memiliki pengaruh terhadap Organizational citizenship behavior dosen.

\section{Pengaruh Motivasi Kerja terhadap Kinerja Dosen}

Berdasarkan hasil pada Tabel 5, diketahui hasil $t$-value sebesar 4,03 >1,96, maka dapat diketahui bahwa variabel motivasi kerja berpengaruh positif terhadap kinerja dosen secara signifikan. Hal ini berarti bahwa semakin tinggi motivasi kerja dosen, 
maka kinerja dosen akan semakin baik pula. Hasil penelitian ini mengindikasikan bahwa motivasi kerja memiliki pengaruh positif dan signifikan terhadap kinerja dosen Perguruan Tinggi Swasta di Medan. Kinerja seorang dosen dipengaruhi oleh beberapa faktor, namun dorongan atau motivasi kerja memiliki peranan yang sangat penting dalam pelaksanaan Tri Dharma Perguruan Tinggi dosen berupa kegiatan pendidikan pengajaran, penelitian, pengabdian kepada masyarakat dan kegiatan penunjang. Hasil penelitian yang mendukung pernyataan ini adalah penelitian dari (Springer, 2011); (Musriha, 2011); (Tangthong, 2014); (Cui et al., 2013); dan (Jayaweera, 2015) yang menyimpulkan bahwa motivasi kerja memiliki pengaruh positif dan signifikan terhadap kinerja dosen. Temuan penelitian ini juga didukung penelitian yang dilakukan oleh (Jufrizen, 2017); (Gultom, 2014); (Sunarsih dan Helmiatin, 2017); (Jusmin et al., 2016); (Hanafi et al., 2018) dan (Narasuci et al., 2018).

\section{Pengaruh Iklim Organisasi Terhadap Organizational Citizenship Behavior}

Berdasarkan hasil pada Tabel 5, diketahui $t$-value sebesar $4,84>1,96$, maka diketahui bahwa variabel Iklim Organisasi berpengaruh positif terhadap organizational citizenship behavior secara signifikan. Dengan demikian semakin baik Iklim Organisasi yang dirasakan dosen, maka Organizational citizenship behavior dosen akan semakin baik pula.

Teori Lewin tentang iklim organisasi menempatkan organisasi itu Iklim dapat mempengaruhi persepsi karyawan miliki tentang peran dan harapan mereka. Karenanya, iklim kerja yang positif memengaruhi karyawan sikap dan perilaku secara positif, yang pada gilirannya memelihara perilaku kewarganegaraan organisasi di antara karyawannya. Hubungan ini lebih jauh dijelaskan oleh teori Pertukaran Sosial (Social Exchange theory) (Podsakoff et al., 2009). Subramani et al., (2016) melakukan penelitian industri otomotif di India. Mereka menemukan bahwa organisasi iklim memiliki dampak positif pada OCB dan komponenkomponennya (altruisme, kesopanan, sportif, hati nurani dan civic virtue). Hasil penelitian lain juga menunjukkan bahwa iklim organisasi berpengaruh terhadap OCB (Pozveh dan Karimi, 2017); (Gholami et al., 2015); (Vasudevan dan Iqbal, 2018) dan (Asari, 2017).

\section{Pengaruh Iklim Organisasi terhadap Kinerja Dosen}

Berdasarkan hasil pada Tabel 5, diketahui t-value sebesar 3,18 > 1,96, maka diketahui bahwa variabel Iklim Organisasi berpengaruh positif terhadap kinerja dosen secara signifikan. Hal ini berarti bahwa semakin baik Iklim Organisasi yang dirasakan dosen, maka kinerja dosen akan semakin baik pula. Interprestasi atas pengaruh itu mengindikasikan peningkatan kinerja dosen pada Perguruan Tinggi Swasta di Medan sebagai akibat pengaruh iklim organisasi adalah nyata. Artinya kinerja dosen akan meningkatkan apabila iklim organiasi yang ada di Perguruan Tinggi tersebut mendukung. Penelitian terdahulu yang dilakukan (Setiawan, 2016) menunjukkan pengaruh yang signifikan antara iklim organisasi terhadap kinerja. Penelitian lain yang dilakukan juga menemukan bahwa terdapat pengaruh yang sangat signifikan iklim organisasi terhadap kinerja (Selamat et al., 2013); (Jusmin et al., 2016); (Lestari et al., 2018); (Pramadewi, 2015); (Shalihin et al., 2018); dan (Anwar et al., 2015).

\section{Pengaruh Organizational Citizenship Behavior Terhadap Kinerja Dosen}

Berdasarkan hasil pada Tabel 5, diketahui t-value sebesar 8,10>1,96, maka diketahui bahwa variabel organizational citizenship behavior berpengaruh positif terhadap kinerja dosen secara signifikan. Dengan demikian semakin baik Organizational citizenship behavior dosen, maka kinerja dosen akan semakin baik pula. Hasil penelitian ini mengindikasikan bahwa OCB dosen Perguruan Tinggi Swasta di Medan memiliki pengaruh yang positif dan signi- 
fikan terhadap peningkatan kinerja dosen, baik dalam kinerja pengajaran, penelitian maupun pengabdian kepada masyarakat.

Robbins dan Judge (2011), menyatakan bahwa organisasi yang mempunyai karyawan dengan perilaku OCB yang baik, akan memiliki kinerja yang lebih baik dibandingkan dengan organisasi lain. Temuan penelitian ini sejalan dengan penelitian yang dilakukan (Ristiana, 2013) dan (Sukmawati et al., 2013) yang berkesimpulan bahwa OCB berpengaruh terhadap kinerja. Penelitian lain yang dilakukan juga menemukan bahwa OCB berpengaruh terhadap kinerja (Li, 2013); (Sani dan Maharani, 2012); (Dwomoh et al., 2019); (Margahana et al., 2018); (Tunggal et al., 2018); (Ariyani et al., 2016) dan (Hakim et al., 2014).

\section{Pengaruh Motivasi Kerja terhadap Kinerja Dosen Melalui Organizational Citizenship Behavior}

Berdasarkan tabel 6 di atas yang berisi kesimpulan bahwa motivasi kerja berpengaruh terhadap kinerja dosen melalui variabel organizational citizenship behaviour, dimana merujuk pada tabel dan output nilai thitungnya sebesar 4,56 yang lebih besar dari 1,96 , dan bobot pengaruhnya sebesar 0,24 . yang artinya organizational citizenship behaviour dapat memediasi secara positif pengaruh motivasi kerja terhadap kinerja dosen dengan bobot sebesar 0,24. Hal ini menunjukkan bahwa motivasi kerja dapat meningkatkan organizational citizenship behaviour dosen yang akhirnya berdampak kepada peningkatan kinerja dosen. Hasil penelitian ini didukung oleh penelitian (Jaya dan Subrata, 2014); (Widyastuti dan Palupiningdyah, 2015) dan (Nurnaningsih dan Wahyono, 2017).

Pengaruh Iklim Organisasi terhadap Kinerja Dosen Melalui Organizational Citizenship Behavior

Iklim Organisasi berpengaruh terhadap Kinerja Dosen melalui variabel Organizational Citizenship Behaviour, dimana merujuk pada tabel dan output nilai $t$ hitung nya sebesar 4,47 yang lebih besar dari 1,96, dan bobot pengaruhnya sebesar 0,24 , yang artinya Organizational Citizenship Behaviour dapat memediasi secara positif pengaruh Iklim Organisasi terhadap Kinerja Dosen dengan bobot sebesar 0,24 . Hasil penelitian ini menunjukkan bahwa iklim organisasi yang baik akan dapat meningkatkan organizational citizenship behaviour dosen yang akhirnya berdampak kepada peningkatan kinerja dosen. Penelitian ini didukung oleh penelitian yang dilakukan oleh Jaya dan Subrata, (2014) dan Lubis, (2015).

\section{SIMPULAN DAN SARAN Simpulan}

Hasil penelitian ini berkesimpulan bahwa motivasi kerja memiliki pengaruh yang signifikan terhadap organizational citizenship behavior, motivasi kerja memiliki pengaruh signifikan terhadap kinerja dosen, iklim organisasi memiliki pengaruh signifikan terhadap organizational citizenship behavior, iklim organisasi memiliki pengaruh signifikan terhadap kinerja dosen dan organizational citizenship behavior memiliki pengaruh signifikan terhadap kinerja dosen, serta motivasi kerja dan iklim organisasi berpengaruh terhadap Kinerja Dosen melalui variabel Organizational Citizenship Behaviour pada Perguruan Tinggi Swasta di Medan. Berdasarkan temuan penelitian, maka hasil penelitian ini mempunyai implikasi sebagai yaitu perlu motivasi kerja dan iklim organisasi yang baik untuk meningkatkan terhadap organizational dan kinerja dosen.

\section{Saran}

Berdasarkan simpulan, maka saran yang diberikan adalah PTS di Medan harus dapat menciptakan iklim organisasi yang baik dengan menjalin hubungan yang baik dan harmonis dosen dengan pimpinan, dosen dengan dosen lainnya, dosen dengan pegawai. Apabila terjalin hubungan yang baik dan harmonis akan bermanfaat bagi dosen agar terhindar dari konflik dan akan berdampak bagi perkembangan dan kemaju- 
an Perguruan Tinggi tersebut. Pihak Manajemen PTS di Medan dapat meningkatkan motivasi dosen dengan memberikan fasilitas yang nyaman, agar para dosen dalam menjalankan aktivitasnya berjalan dengan baik dan nantinya akan meningkatkan kinerja dosen.

Organizational citizenship behavior (OCB) dan kinerja dosen dalam penelitian ini bersifat lokal, khususnya pada PTS di Medan dan karenanya tidak dapat digeneralisasi. Di masa depan, penelitian lain dapat dilakukan di wilayah lain dan atau tingkat pendidikan yang berbeda serta melakukan penelitian dengan variabel-variabel lain, seperti: komitmen organisasi, kepuasan kerja, kepribadian, dukungan organisasi, kualitas interaksi, budaya organisasi, kepemimpinan transformasional dan servant leadership, keterlibatan kerja, kolektivisme dan keadilan organisasi dan variabel lainnya.

Penelitian selanjutnya diharapkan menggunakan metode analisis data yang berbeda, sehingga lebih bisa menggambarkan hasil yang lebih mendekati keadaan yang sebenarnya seperti SEM-PLS. Hasil penelitian ini semoga dapat bermanfaat untuk digunakan sebagai bahan referensi bagi penelitian dengan obyek yang sama untuk dapat memperluas ruang lingkup penelitian tidak hanya pada Perguruan Tinggi Swasta di Medan, tetapi meliputi seluruh perguruan tinggi yang ada di Sumatera Utara.

\section{DAFTAR PUSTAKA}

Ajayi, S. 2015. Effects of Motivation on Employee Productivity: A Case Study of First Bank of Nigeria Plc. https:// papers.ssm.com/sol3/papers.cfm?abstract_ $i$ $d=2700556$

Al-Mahasneh, M. A. 2015. The impact of organizational citizenship behavior on job performance at Greater Amman municipality. European Journal of Business and Management 7(36): 108-118.

Allen, N. J. 2003. Organizational commitment in the military: a discussion of theory and practice. Journal Military Psychology 15(3): 237-253.
Anwar, A. A., H. Maupa, S. Haerani, dan C. Pahlevi. 2015. The Effects of Leadership Styles, Organizational Climate, Environmental Aspects and Organizational Commitment and Job Satisfaction on the Lectures' Performance of Kopertis III in Jakarta. Scientific Research Journal (SCIRJ) III(IX): 37-42.

Ariyani, I., S. Haerani, H. Maupa, dan M. I. Taba. 2016. The Influence of Organizational Culture, Work Motivation and Working Climate on the Performance of Nurses through Job Satisfaction, Organizational Commitment and Organizational Citizenship Behavior in the Private Hospitals in Jakarta, Indonesia. Scientific Research Journal (SCIRJ), IV(VII): 15-29.

Arokiasamy, L., M. Ismail, A. Ahmad, dan J. Othman. 2009. Background of Malaysian Private Institutions of Higher Learning and Challenges Faced by Academics. The Journal of International Social Research 2(8): 60-67.

Asari, A. 2017. Effect of Personality, Organizational Climate, and Work Satisfaction on Organizational Citizenship Behavior Teacher. International Journal of Human Capital Management 1(2): 45-51.

Atkinson, T. dan H. Frechette. 2017. Creating a Positive organizational climate in a negative economic one. Improving Organizational Climate to Transform Performance. Forum 1-3.

Auliana, S. dan I. Nurasiah. 2017. Penerapan Organizational Citizenship Behavior Dosen di STIE Bina Bangsa. Manajerial : Jurnal Manajemen Dan Sistem Informasi 16(1): 149-162.

Benjamin, S. J., M. S. Marathamuthu, S. Muthaiyah, dan M. Raman. 2011. Affordability of private tertiary education: A Malaysian study. International Journal of Social Economics 38(4): 382406.

Borman, W. C., L. B. Brantley, dan M. A. Hanson. 2014. Progress Toward Understanding the Structure and Determinants of Job Performance: A 
Focus on Task and Citizenship Performance. International Journal of Selection and Assessment 22(4): 422-431.

Braton, J. dan J. Gold. 2012. Human Resource Management: Theory and Practice (5th ed.). Palgrave Macmillan. Basingstoke.

Carpenter, M., T. Bauer, dan B. Erdogan. 2010. Principles of Management. Flat World Knowledge, Inc. New York.

Colquitt, J., J. LePine, dan M. Wesson. 2012. Organizational Behavior: Improving Performance and Commitment in the Workplace (3rd ed.). McGraw-Hill Education. New York.

Cui, W., G. Cao, J. H. Park, Q. Ouyang, dan Y. Zhu. 2013. Influence of indoor air temperature on human thermal comfort, motivation, and performance. Building and Environment, 68: 114-122.

Davis, K. dan J. W. Newstrom. 2001. Perilaku Dalam Organisasi (7th ed.). Erlangga. Jakarta.

Dehdashti-Shahrok, Z., H. Abdul-Ali, dan P. D. M. Mohammad. 2012. The Relationship between climate factors and emotional intelligence in organizations. Journal of Tadbiri 23(246): 42-50.

Demirel, Y., I. Elhusadi, dan A. Alhasadi. 2018. The Relationship between Organizational Citizenship Behavior and Organizational Factors. International Journal of Business and Management Invention (IJBMI) 7(3): 27-39.

Dwomoh, G., L. A. Gyamfi, dan A. W. Luguterah. 2019. Effect of Organizational Citizenship Behaviour on Performance of Employees of Kumasi Technical University: Moderating Role of Work Overload. Journal of Management and Economic Studies 1(2): 18-34.

George, J. dan G. R. Jones. 2012. Understanding and Managing Organizational Behavior. Pearson Education, Inc. New Jersey.

Gholami, S., M. S. Keykale, M. Tir, F. D. Ramandi, M. Karimi, dan R. Rajaee. 2015. Investigation the Relationship Between Organizational Climate and Organizational Citizenship Behavior among Staff in Hospital. European Journal of Biology and Medical Science Research 3(3): 54-63.

Glisson, C. dan L. R. James. 2002. The crosslevel effects of culture and climate in human service teams. Journal of Organizational Behavior, 23: 767-794.

Gomes, D. R., V. Asseiro, dan N. Ribeiro. 2013. Triggering Employee Motivation in Adverse Organizational Contexts: "Going the Extra Mile" while Holding Hands with Uncertainty? Business and Management Research 2(1): 41-54.

Gondokusumo, S. dan E. M. Sutanto. 2015. Motivasi Kerja, Kepuasan Kerja, dan Komitmen Organisasional Karyawan. Jurnal Manajemen Dan Kewirausahaan 7(2): 186-196.

Gultom, D. K. 2014. Pengaruh Budaya Organisasi Perusahaan Dan Motivasi Terhadap Kinerja Karyawan pada PT. Perusahaan Gas Negara (Persero) Tbk Medan. Jurnal Ilmiah Manajemen Dan Bisnis 14(2): 176-184.

Hair, J. F., W. C. Black, B. J. Babin, dan R. E. Anderson. 2014. Multivariate Data Analysis (7th ed.). Pearson Education Limited. New Jersey.

Hakim, W. dan A. Fernandes. 2017. Moderation effect of organizational citizenship behavior on the performance of lecturers. Journal of Organizational Change Management 30(7): 1136-1148.

Hakim, W., U. Nimran, S. Haerani, dan S. Alam. 2014. The Antecedents of Organizational Citizenship Behavior (OCB) and TheirEffect on Performance: Study on Public University in Makassar, South Sulawesi, Indonesia. IOSR Journal of Business and Management (IOSR-JBM) 16(2): 5-13.

Hanafi, A., B. B. Soebyakto, dan M. Afriyanti. 2018. The Effect of Organizational Citizenship Behavior (OCB) and Quality of Work Life (QWL) on The Employee Work Performance with Motivation As An Intervening Variables at Industrial affairs Of South Sumatera Province. International Journal 
of Scientific Research and Management (IJSRM) 6(9): 676-685.

Hemakumara, Khatibi, dan D. D. M. G. M. 2018. University Administrative Staff Motivation and Organizational Citizenship Behaviour: Development of a Conceptual Model. International Journal of Arts and Commerce 7(6): 16-24.

Herman, S. S., D. Eaton, dan H. R. Hasbollah. 2014. The motivation of quantity surveyors in the Malaysian construction industry for improved job performance. In Proceeding of National Postgraduate Conference on Business Administration 2014: 1-10.

Hoy, W. K. dan C. G. Miskel. 2001. Educational Administration, Theory, Research and Practices. McGraw - Hill. New York.

Ibrahim, M. A. dan Aslinda. 2014. The Effect of Motivation on Organizational Citizenship Behavior (OCB) at Telkom Indonesia in Makasar. International Journal of Administrative Sciences $\mathcal{E}$ Organization 21(2): 114-120.

Jaya, N. N. dan I. G. M. Subrata. 2014. Model Pengukuran Organizational Citizenship Behaviour (OCB) Dan Produktivitas Dosen PNS Diperbantukan (DPK) Pada Perguruan Tinggi Swasta Di Kota Mataran. GaneÇ Swara 8(1): 91-95.

Jayaweera, T. 2015. Impact of Work Environmental Factors on Job Performance, Mediating Role of Work Motivation: A Study of Hotel Sector in England. International Journal of Business and Management 10(3): 271-278.

Jensen, J. D. 2018. Employee Motivation: A Leadership Imperative. International Journal of Business Administration 9(2): 93-98.

Jex, S. M. dan T. W. Britt. 2008. Organizational Psychology: A Scientist-Practitioner Approach. John Wiley \& Sons. New York.

Jufrizen, J. 2017. Pengaruh kemampuan dan motivasi terhadap kinerja perawat Studi pada Rumah Sakit Umum Madani Medan. Jurnal Riset Sains Manajemen, 1(1): 27-34.
Jusmin, A., S. Said, M. J. Bima, dan R. Alam. 2016. Specific Determinants of Work Motivation, Competence, Organizational Climate, Job Satisfaction and Individual Performance: A Study among Lecturers. Journal of Business and Management Sciences 4(3): 53-59.

Kartini, B. Sujanto, dan M. Mukhtar. 2017. The Influence of Organizational Climate, Transformational Leadership, and Work Motivation on Teacher Job Performance. International Journal of Human Capital Management 1(1): 1922015.

Landy, F. J. dan J. M. Conte. 2016. Work in the 21st century: An introduction to industrial and organizational psychology (5th ed.). Wiley. New Jersey.

Lestari, S. I. P., W. Astuti, dan Sunardi. 2018. The Impact of Organizational Climate on Lecturer Performance: The Role Mediation of Individual Commitment. Journal of Resources Development and Management 48: 32-42.

Li, X. 2013. Chinese school teachers' organizational citizenship behavior (OCB): Predictors and outcomes. PsyCh Journal 2: 146-159.

Litwin, G. H. dan R. A. Stringer. 1968. Motivation and Organizational Climate. Division of Research, Harvard Business School. Boston.

Lubis, M. S. 2015. Pengaruh Iklim Organisasi dan Komitmen Organisasi Terhadap Pembentukan Organizational Citizenship Behavior (OCB) Karyawan Dalam Rangka Peningkatan Kinerja. E-Jurnal Apresiasi Ekonomi 3(2): 75-84.

Lunenburg, F. C. dan A. C. Ornstein. 2011. Educational Administration: Concepts and Practices (6th ed.). Wadsworth Publishing. Belmont, CA.

Luthans, F. 2006. Perilaku Organisasi (10th ed.). Andi Offset. Yogyakarta.

Mahmoudi, G. 2013. Introduction to understanding organizational climate. Vania. Tehran.

Malanao, E. R. P., E. P. Inocian, G. E. A. Amores, dan J. P. Bacarisas. 2015. Work 
motivation and organizational citizenship behavior of employees. UV Journal of Research: 125-134.

Margahana, H., S. Haryono, dan Z. Muftasa. 2018. The Effects of Job Motivation and Job Satisfaction Toward Organizational Citizenship Behavior (OCB) and Its Impact on Job Performance of Paramedical Community Health Centers in the City of Bandar Lampung. Journal of Resources Development and Management 46: 1-10.

Meylandani, D. 2013. Hubungan Antara Iklim Organisasi Dan Organizational Citizens Behavioral (OCB) Pada Perawat RSUD Kanjuruhan Kepanjen Kabupaten Malang. Jurnal Psikologi Universitas Negeri Malang 1(1): 1-13.

Mohamed, W. S. E. D. 2016. Investigating the Relationship between Job Satisfaction and Organizational Citizenship Behavior among Beni Suef Cement Company Employees. Arabian Journal of Business and $r$ A Management Review 6(5): 1-7.

Muchhal, D. S. 2014. HR Practices and Job Performance. IOSR Journal Of Humanities And Social Science (IOSRJHSS) 19(4): 55-61.

Muhammad, G. dan U. Memon. 2012. Determinants of Employee Motivation A Case Study of Afroze Textile Industries Limited, Karachi, Pakistan. IOSR Journal of Business and Management (IOSR-JBM 4(3): 22-25.

Musriha. 2011. Influences of Work Behavior, Work Environmnt, and Motivation In Clove Cigarette Factories In Kudus. Academic Research International 1(3): 303314.

Nabi, M. N., M. M. Islam, T. M. Dip, dan M. A. Al. Hossain. 2017. Impact of motivation on employee performances: a case study of Karmasangsthan bank Limited, Bangladesh. Arabian Journal of Business and Ar A Management Review 7(1): 1-8.

Narasuci, W., M. Setiawan, dan Noermijati. 2018. Effect of Work Environment on
Lecturer Performance Mediated by Work Motivation and Job Satisfaction. Journal of Applied Management (JAM) 16(4): 645-653.

Newland, S. J. 2012. Organizational Citizenship Behavior-Individual or Organizational Citizenship BehaviorOrganization: Does the Underlying Motive Matter? Western Kentucky University.

Nurnaningsih, S. dan W. Wahyono. 2017. Pengaruh Kepuasan Kerja, Motivasi Kerja Dan Komitmen Organisasi Terhadap Kinerja Melalui Organizational Citizenship Behavior (OCB) Sebagai Variabel Intervening. Economic Education Analysis Journal 6(2): 365-378.

Nzulwa, J. 2014. Motivational Factors Affecting High School Teacher's Professional Conduct and Work Performance: A Case of Public High Schools in Nairobi City. International Journal of Humanities and Social Science 4(3): 60-66.

Oren, L., A. Tziner, Y. Nahshon, dan G. Sharoni. 2013. Relation Between OCBS, Organizational Justice, Work Motivation And Self Efficacy. The Protection of Consumer Rights in the Field of Economic Services of General Interes 15(34): 505-516.

Organ, D., P. M. Podsakoff, dan S. B. MacKenzie. 2006. Organizational citizenship behavior: Its nature, antecedents, and consequences. Sage Publication Inc. Thousand Oaks, CA.

Organ, D. W. 1988. Organizational Citizenship Behavior: The Good Soldier Syndrome. Lexington Books/D. C. Heath and Com. Lexington, MA, England.

Osman, A., Y. H. Othman, S. M. S. Rana, M. Solaiman, dan B. Lal. 2015. The Influence of Job Satisfaction, Job Motivation \& Perceived Organizational Support towards Organizational Citizenship Behavior (OCB): A Perspective of American-Based Organization in Kulim, Malaysia. Asian Social Science 11(21): 174-182.

Ostroff, C., A. J. Kinicki, dan M. M. Tamkins. 
2003. Organizational culture and climate. John Wiley. New York.

Penggalih, B. dan R. Zulaicha. 2012. Pengaruh Kepuasan Kerja Terhadap Organizational Citizenship Behavior dengan Motivasi Kerja Sebagai Variabel Intervening Pada Karyawan PT. Telkom Tega. Performance 16(2): 1-15.

Podsakoff, N. P., S. W. Whiting, P. M. Podsakoff, dan B. D. Blume. 2009. Individualand organizational-level consequences of organizational citizenship behaviors: A meta-analysis. Journal of Applied Psychology, 94(1): 122-141.

Pozveh, A. Z. dan F. Karimi. 2017. The relationship between organizational climate and organizational citizenship behaviors of the staff members in the Department of Education in Isfahan city. International Journal of Educational and Psychological Researches 3(1): 53-60.

Pramadewi, A. 2015. Influence of Organizational Climate, Professional Competence of the Work Motivation and Impact on the Performance Faculty of Economics, University of Riau. European Journal of Business and Management, 7(4): 18-24.

Purohit, B. dan A. Wadhwa. 2012. Organisational climate from view point of motivation in district hospital, India. Health 4(7): 400-406.

Purwanti, D. dan N. Mafizatun. 2016. Pengaruh Iklim Organisasi Dan Tipe Kepribadian Terhadap Stres Kerja Dan Perilaku Kewargaan (Studi pada Karyawan Klinik Laboratorium Prodia Cabang Menteng, Jakarta). Jurnal Manajemen 20(2): 293-309.

Raghoebarsing, C. 2011. Organizational Citizenship Behavior \& work motivation in the granite mining industry in WestSuriname. Lim A Po Institute for Social Studies - Maastricht School of Management MBA VI - Management \& Finance.

Ristiana, M. 2013. Pengaruh Komitmen Organisasi dan Kepuasan Kerja Terhadap Organizational Citizenship
Behavior (OCB) dan Kinerja Karyawan Rumah Sakit Bhayangkara Trijata Denpasar. Jurnal Ilmu Ekonomi \& Manajemen 9(1): 56-70.

Rivai, V. 2005. Manajemen Sumber Daya Manusia Untuk Perusahaan Dari Teori ke Praktik (1st ed.). PT Raja Grafindo Persada. Jakarta.

Robbins, S. P. dan T. A. Judge. 2011. Organizational Behavior (14th ed.). Prentice Hall. New Jersey.

Saeed, R., R. N. Lodhi, dan A. Iqbal. 2014. Factors Influencing Job Satisfaction of Employees in Telecom Sector of Pakistan. International Journal of African and Asian Studies 3: 124-130.

Sani, A. dan V. Maharani. 2012. The Impacts of Transformational Leadership and Organizational Commitment on Job Performance with the Among Lecturers of Faculty in the Islamic Maulana Malik Ibrahim Malang University: the Mediating Effects of Organizational Citizenship Behavior. International Journal of Academic Research 4(4): 99-103.

Schneider, B., M. G. Ehrhart, dan W. H. Macey. 2013. Perspectives on organizational climate and culture. Annual Review of Psychology, 64: 361-388.

Selamat, N., N. Z. Samsu, dan N. S. M. Kamalu. 2013. The impact of organizational climate on teachers' job performance. Educational Research EJournal 2(1): 1-12.

Setiawan, K. C. 2016. Pengaruh Iklim Organisasi terhadap Kinerja Karyawan Level Pelaksana di Divisi Operasi PT. Pusri Palembang. Psikis : Jurnal Psikologi Islami 1(1): 23-32.

Shalihin, L. O. M., M. Kamaluddin, L. Iru, dan S. N. Husain. 2018. The Effect of Learning Organization, Organizational Climate, and Work Motivation on Work Satisfaction and Teacher's Performance of Teachers of The State High Schools in Kendari City, Indonesia. International Journal of Education, Learning and Development 6(12): 92-103.

Springer, G. J. 2011. A Study of Job 
Motivation, Satisfaction, and Performance among Bank Employees. Journal of Global Business Issues 5(1): 29-42.

Srivastava, S. K. dan K. C. Barmola. 2011. Role of Motivation in Higher Productivity. Global Journal of Business Management 5(1): 105-116.

Subramani, A. K., N. A. Jan, M. Gaur, dan N. Vinodh. 2016. Impact of organizational climate on organizational citizenship behaviour with respect to automotive industries at Ambattur industrial estate, Chennai. International Journal of Applied Business and Economic Research 13(8): 97114.

Sukmawati, A. Thoyib, dan Surachman. 2013. Peran Organizational Citizenship Behavior (OCB) sebagai Mediator Pengaruh Kepuasan Kerja, Lingkungan Kerja dan Komitmen Organisasi terhadap Kinerja Karyawan. Jurnal Aplikasi Manajemen 11: 547-558.

Sunarsih, N. dan Helmiatin. 2017. Influence of Organizational Climate, Motivation, and Job Satisfaction on Employee Performance. Review of Integrative Business and Economics Research 6(1): 262-276.

Suryabrata, S. 2004. Psikologi Pendidikan. PT Raja Grafindo Persada. Jakarta.

Tangthong, S. 2014. The Effects of Human Resource Management Practices on Employee Retention in Thailand'S Multinational Corporations. International Journal of Economics, Commerce and Management 2(10): 1-30.

Thompson, M. D. 2005. Organizational Climate Perception and Job Element Satisfaction: A Multi-frame Application in a Higher Education Setting. E-Journal of Organizational Learning and Leadership $4(1)$.

Ticoalu, L. K. 2013. Organizational citizenship behavior (OCB) dan komitmen organisasi pengaruhnya terhadap kinerja karyawan. Jurnal EMBA 1(4): 782-790.
Trisnaningsih, S. 2011. Faktor-Faktor yang mempengaruhi Lecturer Performance Akuntansi. Jurnal Akutansi Dan Auditing 8(1): 83-94.

Tunggal, F. H., P. Titisari, dan M. Fathorrazi. 2018. The Effect of Work Motivation on Performance With Organizational Citizenship Behavior As Intervening Variable. International Journal of Business and Management Invention (IJBMI) 7(2): 28-33.

Vasudevan, L. dan A. Iqbal. 2018. Relationship between organizational climate and citizenship behavior of the nonsupervisory staff in Bank Simpanan National, Malaysia. International Journal of Human Capital in Urban Management (IJHCUM) 3(4): 287-302.

Widyastuti, N. dan P. Palupiningdyah. 2015. engaruh Kepuasan dan Motivasi Kerja terhadap Kinerja Karyawan dengan Organizational Citizenship Behavior (OCB) sebagai Variabel. Management Analysis Journal 4(1): 76-78.

Wijatno, S. 2009. Pengelolaan Perguruan Tinggi Secara Efisien, Efektif dan Ekonomis. Salemba Empat. Jakarta.

Williams, L. J. dan S. E. Anderson. 1991. Job satisfaction and organizational commitment as predictors of organizational citizenship and in-role behavior. Journal of Management 17(3): 601-617.

Yozgat, U., S. Yurtkoru, dan E. Bilginoğlu. 2013. Job Stress and Job Performance Among Employees in Public Sector in Istanbul: Examining the Moderating Role of Emotional Intelligence. Procedia - Social and Behavioral Sciences 75: 518524. 